\title{
The Impact of the All-Volunteer Force on Hungarian Officer Training
}

\author{
PETRUSKA Ferenc ${ }^{1}$
}

\begin{abstract}
The Government's goal was partly to replace conscripts with volunteer defence and volunteer operational reserves, and contracted servicemembers, however, the differences between the two systems are very pronounced. The author outlines the consequences of these changes on our military higher education.
\end{abstract}

Keywords: National University of Public Service, Faculty of Military Sciences and Officer Training, salary, military force, education, common modules, officer, all-volunteer force

A decade has passed since the last conscript demobilized in Hungary. The largest and the most difficult period of the transformation of the Hungarian Defence Forces (HDF) came to an end at this moment. The results can already be seen. Hungary, as a member of the European Union and NATO, has a stable security policy situation, it is surrounded by allies, friends and partners. The safety and security of our citizens may be prone to threats originating from conflicts in nearby countries (e.g. Ukraine) and distant nations, and to the strengthening of international terrorism. These risks have to be faced by the Alliance and the European Union, and this struggle is also part of the tasks of Hungary's all-volunteer force (AVF).

\section{From a Conscript-Based to a Volunteer-Based Force}

The first conscripts joined the armed forces of the Austro-Hungarian Monarchy in January 1869. The conscript-based system, in the 136 years up to 4 November 2004 had a continuous impact on Hungarian society, the national culture and the principles relating to national defense. From 1869 to 1890, only a part of the personnel performed active service in the ranks of the defense forces, mainly during basic training and exercises in the autumn. The rest of the staff fulfilled its duty with minor interruptions. 1912 brought changes: active service time was reduced to two years for the entire armed forces. [1]

After the end of World War I and the collapse of the Austro-Hungarian Monarchy, the military clauses of the Peace Treaty of Trianon, signed on 4 June 1920, only allowed the establishment of a recruited force consisting of 35,000 servicemembers, capable only of policing. Only in 1932, was the so-called defense force system, and general conscription re-introduced. In 1939, the Parliament adopted an Act on the use of the Hungarian armed forces in war and subsequently, the development of the defense forces began. One of the greatest disasters for the Hungarian nation was that our servicemembers, during World War II battles on the Eastern Front, took part in the battles and operations under asymetric conditions, resulting in severe losses. By the end of World War II, the Hungarian armed forces had bled

1 National University of Public Service, Hungary, Budapest, E-mail: petruska.ferenc@uni-nke.hu 
out and fallen to pieces. The organization of the People's Army ${ }^{2}$ had already begun during the war, after the formation of the Provisional National Government. In 1949, the communist takeover reshuffled the military's objectives, tasks and structure, and the formation of a mass army began. This process was called the development of the Hungarian People's Army. The foreign and domestic political, social and economic developments, started in the second half of the 80s and accelerated at the end of the decade, led to the complete denial of the former social formation. After the democratic parliamentary elections in 1990, the above processes led to the development of the institution of civil democracy and market economy. [4]

The military has not been left out of the radical transformation processes either, of course. Its transformation, which included the upgrade of the inherited values, military doctrine, organizational structure and armament, was characterized by a strong, but not always consistent endeavor. The transformation of the personnel incurred the biggest conflicts, because reducing the number of a 150,000-strong force to less than its one third caused massive movements on the labor market. The implementation of a modern human resources strategy, which took care of the personnel and taking into account the burden-taking capacity of the country, managed to solve this significant problem without larger and protracted conflicts. [4]

The security policy decision of the National Assembly formed the basis of the transformation, according to which Hungary does not regard any single country as an enemy and wishes to live in peace, seeks cooperation with all the states of the world, rejects the resolution of any dispute by force of arms and only deploys its armed forces if an armed attack is launched against the country's independence and territorial integrity. [2]

The analyses of security risks ascertained that Hungary is not threatened by an armed conflict that would reach the level of war threshold, and therefore, it has become possible to break down former hereditary military structures, reduce the number of personnel and military organizations, rearrange the units' geographical location and upgrade leadership. [2]

In the early 90s, following the democratic transformation of Hungarian society and the consolidation of the institutional system, it became necessary to reconsider the country's international cooperation. The leadership of Hungary declared the nation's Euro-Atlantic aspirations and the intention to join NATO and the European Union. In 1994, one of the first steps of this process was joining the NATO Partnership for Peace (PfP) programme. The HDF prepared for the use of NATO procedures, and ultimately NATO membership through joint exercises and peace support operations (IFOR, ${ }^{3} \mathrm{SFOR}^{4}$ ).

Joining NATO PfP accelerated the acceptance of the Euro-Atlantic values, the distribution and adaptation of the Anglo-Saxon military organization culture, and the profound grounding of Hungary's accession to the Alliance's military organization. [4]

Hungary became a relatively influential player as a member of NATO, much more important compared to its previous capabilities and capable of managing global conflicts. Joining NATO opened a new dimension of security guarantees and obligations for our country, which entailed the need for qualitative transformation of the military force. [1]

An aggregated result of all these factors: the institution of compulsory military service, peace and wartime military supplement significantly changed after 4 November 2004. The HDF was re-established, built on professional and contract employment relationships, based

2 The Hungarian Defence Forces were called Democratic Army from 1949 to 1990

3 Implementation Force in Bosnia and Herzegovina.

4 Stabilisation Force in Bosnia and Herzegovina. 
on the principle of voluntary service, in peacetime no Hungarian citizens must perform conscript military service by law.

The Parliament decided on the transformation, back in 1995, to a mixed military system that consisted of voluntary and conscripted servicemembers. After several important steps, on 24 September 2003, the Government adopted a decision on the transformation of the HDF, according to which a further development was envisaged without military conscription.

The Government, taking office in the spring of 2002, assumed in its program that the country's economic capacity allowed the transformation to an all-volunteer force. The decisions of the Defense Review, initiated in the summer of 2002 and completed a year later, made it possible to rationally adjust the number of personnel and the organization of the HDF, to withdraw a large number of outdated military equipment from the system. The purpose of the Defense Review was to re-formulate the mission and tasks of the HDF, based on national interests and objectives, to define the necessary skills, ranking them according to their importance, and to propose to allocate resources to the capabilities. Amongst the main objectives of the Ministry of Defense (MoD), was an endeavor to develop a transparent defense planning, accountability and management in making effective use of the taxpayers' money. International examples show that the maintenance of an armed force, consisting purely of volunteers, is cost-effective in the long run. While personnel costs are higher, the defense management, preparation, training, maintenance and repair of equipment will be less expensive. Foreign examples also show that, due to a higher level of education of the voluntary force, they carry out the tasks of national and alliance obligations alike more effectively. This can be ensured by effective recruitment, a transparent career model for the individual, professional training and creating safe retirement after discharge of the armed forces. [6]

On 14 February 2003, the Government discussed a proposal relating to the transition to an all-volunteer force and made arrangements to start the administrative preparation of the decision. The transition to a volunteer force is actually a response to the security challenges of our era. It contains a significant structural change, a new type of military training, and the preparation of a new military culture. [6]

On 8 November 2004, the Parliament adopted Act CV of 2004 on National Defense and the HDF, and in this context, it amended the (then) Constitution of Hungary (now Fundamental Law). The new Defense Act, in conjunction with the defense of the homeland, only imposes burdens on the population if it is absolutely necessary. Basically, the Defense Act regulated the transition to an volunteer force, and stipulated the new rules of the military force with a changed structure and composition. Volunteer military personnel performing active service in peacetime are regular servicemembers, government servants and public employees, employees under the Labor Code and voluntary reservists, available for service from time to time. [6]

The task of volunteer defence reserves, both in peacetime and classified periods, are to guard and protect military installations and the critical infrastructure, and provide host nation support. This staff is assigned to guard positions of war personnel of military organizations, and in peacetime, it performs the security and guarding duties at the designated facilities of the HDF. They are armed security guards and employees of the MoD Electronics, Logistics and Property Management Plc. They are partly ex-policemen, servicemembers, persons fulfilling security patrol and new employees. [1] 
Volunteer operational reserves perform their duties in already existing military organizations or are assigned to units to be established in a classified period, registered in the full board of personnel of the HDF. These reserve positions have paramount importance in ensuring the defense of Hungary. We are dealing primarily with assignments, whose supplement in peacetime with regular personnel is not inevitable or is not ensured, however, their preparation is required to be able to perform their jobs already in peacetime. These reservists can make up for human resource shortages during their active service. Thus, they may be assigned to positions that have not been filled for a long time, or to domestically replace those in operations abroad, or may perform specific tasks occurring intermittently or take part in peace support operations, taking into account their military and civilian expertise, qualifications and suitability.

By suspending conscription, the Hungarian Defence Forces, as a large actual employer in the country, created hundreds of jobs, which contribute to a reduction in the number of unemployed young people. The new tasks of the HDF focus more on international cooperation tasks than before. The valid regulations allow for a multi-stage transition from peacetime operation to deployment activities. Establishing and operating an all-volunteer force means much more than modernization. It includes a new grounding of principles, guiding values, command and control and training methods, deployment and, last but not least, conditions.

After joining NATO and accession to the European Union (EU) on 1 May 2004, Hungary's geopolitical situation and security has fundamentally changed and strengthened. NATO is the most important factor in the stability in Europe, and in the foreseeable future, it is the only political and military regional security institution that is able to guarantee the defense of its member states. Ironically, in our globalized world, Hungary's interests, as a NATO and EU member state, are directly affected by outlying regions. The terrorist attacks on 11 September 2001 against Washington, D.C. and New York have also proved that NATO member states are required to find responses to new security challenges far away from their borders, since Hungary as a member state is simultaneously a participant and also a beneficiary of the political and military system of global security. [2]

The HDF of the $21^{\text {st }}$ century must be able to effectively contribute to the changed circumstances, adapting to the new challenges, to enforce the national security interests of Hungary. Therefore, besides an all-volunteer force, a professional force was formed, which, in addition to the implementation of the tasks set out in the Fundamental Law, the ability to effectively contribute to the peace and security in the Euro-Atlantic area. [6]

Another purpose of the military organizational changes is to ensure the fulfillment of the country's commitments to NATO and the European Union. During the review of the system of military tasks of the HDF, a new demand appeared in the form of a contribution to the rapid response capabilities, developed within the European Union. As a result of these steps, Hungary needs a professional military force, with modular architecture, including specialized elements, smaller in numbers and financially sustainable. [6]

The index of public confidence towards the HDF as a national institution, meant to defend the country, has been constantly high since the change of the political system. The country trusted the servicemembers' devotion to their profession, and highly appreciate their skills. However, criticism of the institution of conscription jeopardized the prestige of the entire armed forces. Therefore in 2004 the MoD set a goal, with a simultaneous transition to an all-volunteer force, to consolidate social support, maintain the confidence and agreement of 
the population towards understanding the country's international engagement and raise the prestige of a military career. [6]

In the area of public relations, the MoD has strengthened its cooperation with organizations that helped our smooth accession to the EU. In addition, it paid particular attention to cooperating organizations in connection with alliance membership and the liaison with NGOs to promote the cultivation of the traditions of the HDF and the public awareness of the armed forces. Through their involvement, it shows the most basic strategic goals to the public. The cooperation is based on the respect towards each other's sovereignty and, in parallel, the enforcement of mutual interests. The MoD continued to expand its cooperation with the local governments and public education and higher education establishments as well. [2]

As a result of the above changes, it was possible to create a high level of public support for the HDF in 2014, and at the same time, the Hungarian armed forces retained its public recognition due to its international involvements. Hungarian society recognizes the HDF's efforts. Society recognizes that, today, highly skilled Hungarian servicemembers perform their service with international recognition, but unfortunately still with outdated equipment. The training level and preparedness of Hungarian servicemembers is improving and it has been enriched with significant international experience in recent years. Career and contract servicemembers previously merely performed security and guarding functions or other support tasks. They are now able to fulfill real military tasks as well. Our servicemembers demonstrated all of these capabilities in Afghanistan, Iraq and other places in the world. [2]

Hungary's defense capabilities ensure the country's highly regarded contribution to peace and security in the Euro-Atlantic area. The work carried out during the military transformation has also been directed to encourage the Government, according to the Hungarian foreign policy objectives and careful analyses of the current European security environment, to ensure the reliable foundation of the Hungarian military modernization capabilities.

Hungary constantly needs servicemembers assuming the armed defense of the country, professionally prepared, physically and psychologically fit senior officers and officers, non-commissioned officers (NCOs) and contract servicemembers with appropriate knowledge, expertise, high level of training, and also volunteers whose mission is a noble one, carrying the values of patriotism, dedication, courage, sacrifice, camaraderie and solidarity. Only servicemembers, prepared and trained at a high level and who regard their military career as their vocation of life, are able to meet these challenges. These are the people who are willing to endanger their lives and be away from their families in remote missions.

During the structural transformation of the HDF, a radical change was performed at unit level, where the period of stabilization and technical upgrade and salary increase started this year. The most important thing is that, during the next four years, the servicemembers' salaries will be raised by an average total of 50\%. From mid 2015, an average 30\% salary increase will represent the first step. [2]

Career and contract servicemembers are rightly proud of the work that they performed during international and domestic tasks in mission in recent years; in particular to ensure the preparedness of national defense, in order to achieve the objectives of modernization stipulated by the Defense Review and the transition of an all-volunteer force. From 2015, a period of stability and predictability allows more attention be devoted to, in addition to their official duties, camaraderie, renewal of the service culture, strengthening the cohesive force of military communities, an appreciation of human values, also to respect disciplinary and 
ethical norms. The inception of the all-volunteer force provides the ground for the HDF to become more professional in the coming years. [2]

The development of the new military career model began in 2010. Its most important elements compose the human resources strategy of the HDF in the period between 2012 and 2021. Its purpose is the development of a new, attractive and credible military career model. In the framework of the Magyary Zoltán Public Administration Development Program, human resources functions connecting public services have been developed, public administration modules and subjects have been introduced in military higher education. [2] [14]

Currently, there is a clear career path before each servicemember in the predictable advancement system of the HDF. The rigorous evaluation system aims at enabling only the finest servicemembers to serve the defense of the homeland. This is supported by reformed NCO and officer training. In the new promotion system, each servicemember can choose from two types of career paths. The target may be a higher or command position, specialization or expertise in any personnel category. The career model of the HDF supports both career paths. Concerning salary management, personal expenditures do not reach $50 \%$ in HDF, in contrast to most of the NATO military forces (there is a NATO member, where this figure is around $70 \%{ }^{5}$ ). [2]

The basis of the current human resources strategy of the HDF is characterized by a credible and attractive military career model, uniform job circumstances and a uniform system of salaries, allowances, subsidies, coordinated with other public service careers. A military career is based on outstanding and regularly checked performance, professionalism and personal motivation. The basis of the performance evaluation system supporting the functioning of the military career model is the joint service methodology. The Public Service Performance Evaluation System (PES) contains an assessment of individual job performance requirements, and the assessment of competence-based work conduct (these are mandatory/identical elements of all three cadre categories), but, besides the afore-mentioned, it assesses the special defense characteristics: physical fitness and military training tasks. The determination of requirements and assessments has been done since the beginning of 2015. The assessment of officers and senior NCOs will be held annually, and occasionally for junior NCOs. The functioning of the PES is supported by a special software in the case of officers and NCOs. In the case of officer cadets and NCO students and volunteer reserve servicemembers, it takes place manually with the help of individual assessment sheets. [14]

The center of the evaluation system is the Military Examination Center of the Faculty of Military Science and Officer Training of the National University of Public Service (NUPS), which serves the unbiased measurement of the general military knowledge of servicemembers. The Military Examination Center, besides supervising and implementing the examinations, coordinates the elaboration of curricula of the examinations, registers the applicants and evaluates the results. [7] [11]

The establishment of human resources (HR) offices also serves to support military careers. [11]

An important component of the military career model is predictable advancement. Every year, an advancement ranking is made of servicemembers who are planning for advance-

5 In the near future, besides personnel expenditures, technical upgrade will also be funded: in 2015, the upgrade of the HDF Pápa Airbase, the costs of which may exceed even USD 80 M in the coming years. These resources will be allocated by the Ministry of National Economy for the MoD. [2] 
ment, compiled by the HR Directorate of the Defence Staff. In the process advancement planning of the HDF - except for assignments in chief warrant positions that are made at local level - central planning is decisive. Appointments to senior positions, coordinated by the HR Directorate of the Defence Staff, are the results of cooperation of competent commanders, professional managers and qualified individuals. If a servicemember no longer has the possibility to advance, he will get the opportunity to use the knowledge acquired to find a job as a public employee, such as a police officer. [2]

One of the most important elements of the model is to create interoperability between public services. Ensuring the opportunity to be further employed, following the closure of an active military career is also a part of the career model. The aim is to provide an opportunity to all military officers who leave the armed forces, to be able to continue as government servants. [14]

Those leaving through no fault of their own may become part of a special group in standby personnel status, the so-called public service reserve personnel, creating the basis for being transferred from cadre (professional) service relationship to another field of public administration. At NUPS the same training and education is provided to police and military officers, and civilian officials through a joint module of up to 15 subjects. Due to this, those graduating, may later work in other fields as well. [14]

\section{The Transformation of Officer Training}

Since the suspension of conscription, citizens' knowledge of home defense has significantly decreased, an increasing proportion of the population does not have any knowledge of the defense of the homeland. This fact incurs the danger that our country's citizens in relation to compulsory military duty, in a special legal order, would not have any knowledge of the obligations imposed on them, and the persons not of servicable age, business organizations and other members of the society will not know their rights and obligations under the Defense Act. This may decrease the defense capability of the country as well, but in a preventive defense situation it would slow down, even in an optimal case, the introduction of a general draft, deteriorating the country's defense capabilities with immediate effect. [7]

It is essential that, from primary to tertiary education, at all levels, both the knowledge concerning home defense issues and the HDF and the knowledge concerning the Fundamental Law in relation appear. [7] [11]

In military science training, in particular, this knowledge must be highlighted. One of the basic aims of higher education is to publicize the significance of home defense, sovereignty, missions, tasks and activities of the HDF, and its role under the Fundamental Law, and through these notions to develop a relationship towards home defense. The system of military higher education will be able to provide such a way, in the long run, in order that professional servicemembers be always familiar with the framework of the legal functioning of the country, and within it, of defense, and to have information on the missions and tasks of the HDF and on the safeguarding of the sovereignty of the country. The development of this training system is the direction that is suitable for acquainting the wider public with knowledge of defense, and at the same time serving the effective functioning of public administration of the country before and during classified periods.

Peace support training and public service interoperability became two newly emphasized elements of officer training. The reason for preparing peace support is our country's broad 
international participation, as described in detail in the previous chapter. The training sessions go on in the framework of the subject peacekeeping knowledge, ${ }^{6}$ the students receive credit points for the allocated lesson hours and the subject is completed by issuing a practical evaluation mark. As of 17 November 2014, the HDF took part with 659 persons ${ }^{7}$ in such operations. [12]

In the spirit of interoperability, officer undergraduates prepare themselves during two terms in 250 hours to pass the public administration exam. ${ }^{8}$ During their studies for the public administration basic exam, they acquire the general public administration knowledge necessary for their everyday work. [14]

Public service interoperability, the mobilization between cadre categories, is strengthened by a public service common module, since September 2013, which resulted in the teaching of 15 common subjects to cadets. The subject of policing theory and law enforcement instruments provides insight into the concepts of policing and organizational systems. The subject of military operations and military theory deals with strategy. Security studies deal with the European Union and NATO organizations. Constitutional law deals with the Fundamental Law and the Hungarian legal system. The subject of State Organization deals with the operation of these organizations. The subject of Disaster Management Administration teaches the cadets protection against disasters. The subject of National Security Studies deals with the detection and management of risks, threats and dangers related to national security and the national security organisations. The subject of Public Administration Functions and Operation teaches undergraduate officers the duties of public administration. The subject of Political Science describes the social and economic system. General Sociology describes social stratification, mobility, cultures and norms. The subject of Leadership and Management Theory deals with managerial career, organization conflicts, including how to solve them. The subject of Public Service Logistics introduces to officer cadets the basic logistics concepts. Public Services and State Budget Theory advances the student towards understanding academic subjects such as economy and public finances, subsystems and other factors affecting them. During joint public service exercises they practice in real-life situations. [14]

One of the aims of officer training is to enable future officers to fulfill general tasks (e.g. command and control), non-commissioned officers to perform specialist tasks (e.g. communications). Related to this, after specialization, in officer training and after the preparation and adoption of the model curricula, starting from the 2013/2014 academic year, the following three basic courses are offered: military leader (infantry, armored, reconnaissance, artillery, engineering, air defense and chemical defense), military logistics (transport, defense technology, military supply) and military operators (radio-electronic reconnaissance and electronic warfare, military information technology, communications, air traffic control, military flight engineers). If we consider that, at the Military Sciences and Officer Training

6 For instance, 15 undergraduates of NUPS took part in basic training on 24-28 November 2014 at the HDF Peace Support Training Centre.

7 Based on the lecture "Transformation of the Hungarian Defence Forces", delivered by Colonel Tibor Jancsekor on 4 December 2014 at the $10^{\text {th }}$ Anniversary of the All-Volunteer Force in Hungary Workshop.

8 Public administration basic exam must be taken after establishing public servant or government servant status: within one year in case of a junior clerk, within two years in case of a desk officer, otherwise the status of the public servant terminates by force of law. During the preparation for public administration basic exam, public servants with different school certificates acquire their general public administration knowledge necessary for their everyday work. 
Faculty of the NUPS, only one year ago, 11 basic courses were taught, the trend is clear.The further changes in officer training, associated with the suspension of conscription, are that the subordinate personnel are, at the most, trained but not educated by officers. The subordinates (volunteer reserves and contract servicemembers) are nowadays "employees" and do not serve based on military obligation. The subordinate staff is especially screened for physical, mental and health conditions after entering the files, where proper schooling is only one of the basic criteria. The officer corps may demand incomparably more of the current contract personnel than of the conscripts compelled to be drafted, sometimes struggling with social and educational problems. [14]

Led by the dean, the Faculty of Military Sciences and Officer Training of the NUPS, at present, Hoi carries out the training of officer undergraduates, preserving military traditions and meeting the contemporary challenges, in a cyclic training system, which consists of BSc and MSc level education of military cadets and officers. The Military Examination Center serves for the measurement of general military knowledge of servicemembers. The center coordinates the development of teaching materials of exams in addition to conducting the exams, registers the exam candidates and evaluates their test results. [14]

The dean, within the framework of the Military Leadership Training Institute, the Military Operators Institute and the Military Logistics Institute of the Faculty of Military Sciences and Officer Training of the NUPS, directs education and training, and the military science and technical research. The faculty institutes have highly trained military instructors and advanced specialized classrooms and labs, equipped with instruments of international standards. The senior management staff courses, retraining and refresher courses at the Faculty of Military Sciences and Officer Training of the NUPS also offer a high-level individual specific knowledge basis for the undergraduates. [14]

The Foreign Language Training Centre ensures the acquisition of language skills and the Language Exam Centre conducts examinations. Undergraduates, students and other course participants may reach a general level in English, and under specialized language training, a STANAG 3 level. In French, they may acquire an adequate level in the ARMA ${ }^{9}$ language exam. [14]

\section{Summary}

Since the radical transformation of military officer training, and in general, of the defense and public administration system, such a short time has passed that it is yet impossible to evaluate them. For the time being, one may ascertain that they are supported by both military personnel (salary increase, public administration interoperability, etc.) and the society. The brand new evaluation system aims at enabling only the finest and most respected servicemembers to serve the defense of Hungary. The purpose of this article is to summarize the legal processes, public and defense administration, and the main objectives of the Ministry of Defense as well. By these processes Hungary became a relatively influential factor in NATO, especially much more influential through its capabilities of managing regional and global conflicts. This radical transformation has opened new dimensions of security guarantees for Hungary, which is highly important during the present regional conflict in Europe.

9 ARMA is an accredited bilingual military professional language exam system, which is available in nine languages (English, French, German, Italian, Croatian, Serbian, Slovakian, Russian and Ukrainian). 


\section{References}

[1] KÁDÁR P., VANYUR T.: Szemelvények a magyar önkéntes tartalékos rendszer múltjáról, jelenéről és jövőjéről. (Excerpts from the Hungarian volunteer reserve force system’s past, present and future - only in Hungarian.) Hadtudomány 3-4 (2013), 82-96.

[2] HENDE Cs.: Az önkéntes tartalékos rendszer kiállta az első próbát. (Hungarian volunteer reserve forces system has proved the first test - only in Hungrian.) Vasárnapi Újság, Magyar Rádió (16 June 2013)

[3] KÁDÁR P.: Megjegyzések az önkéntes tartalékos rendszer felülvizsgálatának margójára. (Notes on the margin of the review of the Hungarian volunteer reserve force system.) Hadtudomány, 1 (2009), 47-56.

[4] UJHÁZY L.: Tartalékos szövetségek a NATO-ban. (Reserve Associations in NATO - only in Hungarian.) Budapest: NKE, PhD-értekezés, 2011.

[5] KÁDÁR P.: A Magyar Honvédség tartalékos rendszerének fejlesztése - mikor, ha nem most? (Development of the Hungarian reserve force system - when, if not now? - only in Hungarian.) Honvédségi Szemle, 1 (2011), 2-7.

[6] LAKATOS L.: Az önkéntes tartalékos rendszer fejlesztésének időszerű kérdései. (Pressing questions of the development of Hungarian volunteer reserve force system - only in Hungarian.) Új Honvédségi Szemle, 3 (2009), 8-10.

[7] KatonaSuli Program. (Military Academy Program - only in Hungarian.) www.katonasuli.hu (downloaded: 3112 2014)

[8] Reserve Forces Act 1996. www.legislation.gov.uk/ukpga/1996/14/contents (downloaded: 31 12 2014)

[9] 1993. évi CX. törvény a honvédelemröl. (pervious National Defence Act I.)

[10] 2004. évi CV. törvény a honvédelemről és a Magyar Honvédségről. (National Defence Act.)

[11] 80/2008. (VI. 13.) OGY határozat a Magyar Honvédség önkéntes tartalékos rendszerének felülvizsgálatáról. (Parliament Decision No. 80/2008. on the review of the Hungarian allvolunteer reserve system.)

[12] 2001. évi XCV. törvény a Magyar Honvédség hivatásos és szerződéses állományú katonáinak jogállásáról. (Act XCV. of 2001 on status of soldiers of Hungarian Defence Forces.)

[13] 2012. évi CCV. törvény a honvédek jogállásáról. (Act CCV. of 2012 on status of soldiers of Hungarian Defence Forces.)

[14] 2011. évi CCIV. törvény a nemzeti felsőoktatásról. (Act CCIV. of 2011 on national higher education.) 